\title{
Late attacks of paroxysmal ocular tilt reaction
}

回蛋

Figure MRI shows the calcified right-sided lesion of the thalamus and mesencephalon at the site of prior bleeding
Supplemental data at Neurology.org

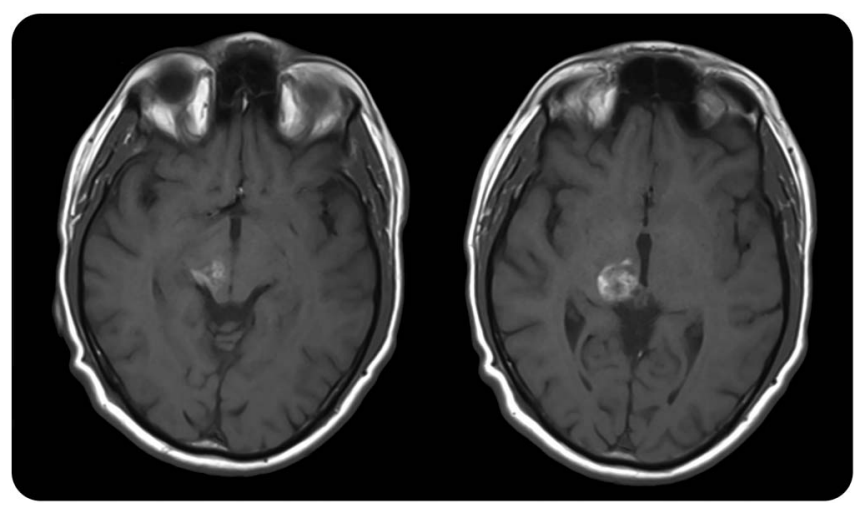

A 54-year-old patient had a right mesodiencephalic hemorrhage in 1992, with residual double vision until 2000. He was symptom-free until 2010, when he developed fluctuating diplopia. We observed paroxysmal attacks of a right ocular tilt reaction (OTR) (video at Neurology.org), whereas in the interval he had a left OTR. MRI showed a calcification of the preexisting lesion (figure). The attacks are apparently caused by an excitation of the right interstitial nucleus of Cajal (INC), ${ }^{1}$ as supported by the effectiveness of carbamazepine (100mg b.i.d.). The delayed onset can be explained by a reorganization of the excitatory and inhibitory synapses found in the INC. ${ }^{2}$

\section{Olympia Kremmyda, MD, PhD, Claudia Frenzel, Michael Strupp, MD, FANA, FEAN}

From the University Hospital, Campus Grosshadern, Munich, Germany.

Author contributions: Olympia Kremmyda: analysis and interpretation of data, drafting the manuscript. Claudia Frenzel: acquisition and interpretation of data. Michael Strupp: interpretation of data, critically revising the manuscript for content.

Acknowledgment: The authors thank Katie Ogston for copyediting the manuscript.

Study funding: No targeted funding reported.

Disclosure: O. Kremmyda receives academic funding from the German Ministry of Education and Research. C. Frenzel reports no disclosures relevant to the manuscript. M. Strupp is Joint Chief Editor of the Journal of Neurology, Editor-in-Chief of Frontiers of Neuro-otology, and Section Editor of F1000. He has received speaker's honoraria from Abbott, Actelion, Biogen, Eisai, GSK, Henning Pharma, Interacoustics, MSD, Otometrics, Pierre-Fabre, TEVA, and UCB. He acts as a consultant for Abbott, Actelion, and Sensorion. Go to Neurology.org for full disclosures.

Correspondence to Dr. Kremmyda: Olympia.kremmyda@med.uni-muenchen.de

1. Oh SY, Choi KD, Shin BS, Seo MW, Kim YH, Kim JS. Paroxysmal ocular tilt reactions after mesodiencephalic lesions: report of two cases and review of the literature. J Neurol Sci 2009;277:98-102.

2. Horn AK, Helmchen C, Wahle P. GABAergic neurons in the rostral mesencephalon of the macaque monkey that control vertical eye movements. Ann NY Acad Sci 2003;1004:19-28. 


\title{
Neurology
}

\author{
Late attacks of paroxysmal ocular tilt reaction \\ Olympia Kremmyda, Claudia Frenzel and Michael Strupp \\ Neurology 2016;87;1304 \\ DOI 10.1212/WNL.0000000000003139
}

This information is current as of September 19, 2016

$\begin{array}{ll}\begin{array}{l}\text { Updated Information \& } \\ \text { Services }\end{array} & \begin{array}{l}\text { including high resolution figures, can be found at: } \\ \text { http://n.neurology.org/content/87/12/1304.full }\end{array} \\ \text { Supplementary Material } & \text { Supplementary material can be found at: } \\ & \text { http://n.neurology.org/content/suppl/2016/09/19/WNL.0000000000003 } \\ & 139 . D C 1 \\ & \text { This article cites } 2 \text { articles, } 0 \text { of which you can access for free at: } \\ & \text { http://n.neurology.org/content/87/12/1304.full\#ref-list-1 } \\ \text { References } & \text { This article, along with others on similar topics, appears in the } \\ & \text { following collection(s): } \\ \text { Diplopia (double vision) } & \text { http://n.neurology.org/cgi/collection/diplopia_double_vision } \\ \text { Subspecialty Collections } & \text { Intracerebral hemorrhage } \\ & \text { http://n.neurology.org/cgi/collection/intracerebral_hemorrhage } \\ & \text { Ocular motility } \\ \text { http://n.neurology.org/cgi/collection/ocular_motility } \\ \text { Information about reproducing this article in parts (figures,tables) or in } \\ \text { its entirety can be found online at: } \\ \text { http://www.neurology.org/about/about_the_journal\#permissions } \\ \text { Information about ordering reprints can be found online: } \\ \text { http://n.neurology.org/subscribers/advertise }\end{array}$

Neurology ${ }^{\circledR}$ is the official journal of the American Academy of Neurology. Published continuously since 1951, it is now a weekly with 48 issues per year. Copyright (O 2016 American Academy of Neurology. All rights reserved. Print ISSN: 0028-3878. Online ISSN: 1526-632X.

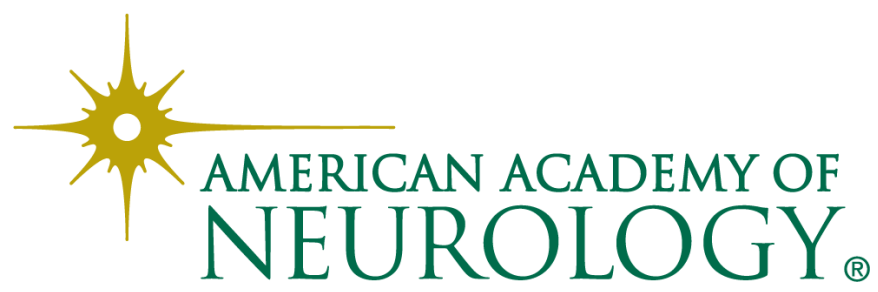

